\title{
Ayrımcılığa Covid-19 Sürecinden Bir Bakış: Temel Kuramlar, Yaş̧̧ılık Tartışmaları ve Öneriler
}

\section{Ageism During the Covid-19 Pandemic: Discussion and Recommendations}

\author{
H. Andaç DEMİRTAŞ MADRAN ${ }^{1}$ ()
}

'Prof. Dr., Başkent University, Faculty of Communication, Department of Public Relations, Ankara, Turkey

ORCID: H.A.D.M. 0000-0001-5582-2608

Sorumlu yazar/Corresponding author:

H. Andaç Demirtaş-Madran, Başkent Üniversitesi, İletișim Fakültesi, Ankara, Türkiye

E-posta/E-mail:

andac@baskent.edu.tr

Geliș tarihi/Received: 24.12 .2020

Revizyon talebi/Revision Requested: 29.01.2021 Son revizyon teslimi/Last revision received: 10.05.2021

Kabul tarihi/Accepted: 29.04 .2021

Atıf/Citation: Demirtas-Madran, H. A. (2021). Ayrımcilığa Covid-19 sürecinden bir bakış: temel kuramlar, yaşçlık tartışmaları ve öneriler. Connectist: Istanbul University Journal of Communication Sciences, 60, 63-90. https://doi.org/10.26650/CONNECTIST2021-846399 öz

Illk olarak 2019 yılının aralık ayı sonunda Çin'in Wuhan eyaletinde belirlenmiş olan yeni tip koronavirüs, Dünya Sağlık Örgütü tarafından 11 Mart 2020'de "pandemi" olarak nitelendirilmiştir. Covid-19 pandemisi sadece fiziksel sağlığı etkilemememiş, tüm dünyada ekonomik, eğitimsel, psikolojik ve toplumsal sorunlara yol açmıştır. Şiddet olaylarını tetikleyen "ayrımcılık" eğiliminde de belirgin bir artış olduğu, önyargı ve ayrımcılığın salgınla aynı hızda tüm dünyaya yayıldığı gözlenmiştir. Bu tür olağanüstü durumlarda yaşanan ayrımcılığın kalıcı ve değişime dirençli olduğu bilinmektedir. Bu ayrımcılık türü kurbanlarda yarattığı hasarın yanı sıra, halkın önlemlere ve kısıtlamalara yönelik tutumlarına, sağlıkla ilgili politikaların oluşturulmasına da etki etmektedir. Bu nedenle son derece önemli bir insanlık sorunu olan ayrımcılıkla bu tür özel durumlarda daha güçlü bir şekilde mücadele etmek gerekmektedir. Varlığından çok haberdar olunmayan bir ayrımclık türü olan "yaşçılık" da bu dönemde hızla yayılmıştır. Bu makalede Covid-19 salgını döneminde artan yaşçılığı temel kuramlar ve güncel bulgular ışı̆̆ında irdelemek amaçlanmaktadır. Bu amaçla, öncelikle ayrımcılık ve yaşçlık üzerinde durulmuş ve ilgili kavramlar tanımlanmıștır. Ardından Psikanalitik Kuram, Evrimsel Yaklaşım, Sosyal Kimlik Kuramı, Yükleme Kuramı ve Terör Yönetimi Kuramı gibi temel kuramsal yaklaşımların yaşçlığa ilişkin açıklamaları üzerinde durulmuştur. Ayrımcılığın pandemi dönemlerine özgü doğası ve bu süreçte tırmanan yaşçlık ilgili kuramlar rehberliğinde irdelenmiş, Covid-19 salgını sırasında tüm dünyada ve Türkiye'de yaşçıı̆̆ın ortaya çıkış şekilleri güncel araştırma bulguları doğrultusunda ele alınmış, konunun medyaya yansıyışı üzerinde durulmuştur. Son olarak, bu süreçte yaşçılıkla mücadele etmek için altının çizilmesi gereken gerçekler ve çözüm önerileri tartışılmıştır. Sonuç olarak bu çalışmada güncel araştırmalar ışığında Covid-19 pandemisi döneminde tüm dünyada ayrımcılık eğiliminde belirgin bir artış gözlendiği, ancak özellikle yaşçılığın belirli yaş gruplarındaki bireylere dayatılan kısıtlamaların da etkisiyle salgınla aynı hızda yayıldığı ortaya konmuştur. Bu durumun, bilimsel bulgularla belgelenen olumsuz sonuçları da gözönüne alındığında, çok disiplinli bir yaklaşım gözetilerek yürütülecek bir mücadeleyi gerektirdiği açıktır.

Anahtar Kelimeler: Önyargı, ayrımcılık, yaşçılık, yaşa dayalı ayrımcılık, Covid-19 


\begin{abstract}
The spread of the coronavirus disease 2019 (Covid-19) was labeled a "pandemic" by the World Health Organization on March 11, 2020. It has caused not only health-related issues but also economic, educational, psychological, and social problems. Further, discrimination associated with the pandemic has been observed around the globe. Besides the obvious negative consequences faced by the individuals targeted, pandemic-related discrimination has affected the spread of the virus by influencing public attitudes toward disease prevention and the restrictions imposed by authorities. Discrimination toward foreigners, minorities, and certain religious groups (e.g., Muslims) increased during this period. Additionally, the pandemic saw ageism spread rapidly to become more visible than ever. Acknowledging
\end{abstract}

that Covid-19 poses a higher risk for individuals over a certain age, several countries implemented restrictions specific to those age groups. However, this practice resulted in the emergence of problems that were not considered initially, especially the escalation of ageism. This study examines ageism during the Covid-19 pandemic based on major theories and current research. First, discrimination and ageism are defined in detail. Then, pandemicrelated ageism is discussed within the framework of basic theoretical approaches. Finally, recommendations for preventing ageism related to the pandemic and in general are presented. .

Keywords: Prejudice, discrimination, ageism, age-based discrimination, covid-19

\section{EXTENDED ABSTRACT}

The coronavirus disease 2019 (Covid-19) was first detected in the Wuhan province of China in late December 2019, and the outbreak was announced as a Public Health Emergency of International Concern on January 30, 2020. On March 11, 2020, it was labeled a"pandemic" by the World Health Organization. This pandemic has caused not only health-related issues but also economic, educational, psychological, and social problems at a global scale. During the pandemic, a significant increase in prejudice and acts of discrimination has been witnessed, triggering violent incidents across the world.

Prejudice and discrimination have simultaneously grown worldwide during the Covid-19 pandemic, as seen previously during the SARS and AIDS epidemics. Research indicates that the discrimination that emerges during such global health crises is a highly persistent problem that is resistant to change. Besides the obvious negative consequences faced by those individuals targeted, pandemic-related discrimination affects public attitudes toward the establishment of health-related policies, social restrictions, and the prevention of the spread of the virus. Therefore, it is important to confront all types of pandemic-related discrimination, which have become a human rights violation issue. Verbal, non-verbal, physical, and other forms of discrimination against foreigners, minorities, Muslims, healthcare professionals, and individuals of 
Chinese (or even East Asian) origin have escalated during the Covid-19 period across many countries. The novel coronavirus has also been referred to by some as the "Wuhan virus" or the "Chinese virus."

Ageism has spread rapidly and become more visible than ever during the Covid-19 pandemic. It can be defined as any action that is directed toward members of a certain age group. Ageism refers to a person or persons behaving differently toward others based solely on their membership of a specific age group; it is directed mostly to older people. Acknowledging that Covid-19 poses a higher health risk for individuals over a certain age, many countries have implemented restrictions and specific measures for those in the at-risk age group. Although this practice is aimed at protecting such individuals, it has resulted in the emergence of problems that were not considered initially, especially the escalation of ageism. Social media-based analyses have shown an approximately tenfold increase in the use of hateful and offensive language targeting certain groups, including older people. Ageist hashtags such as "\#boomerremover" and "\#grandmakiller" have been used on various social media platforms. In the fight against ageism related to Covid-19, it is important to understand the process, related concepts, and motivations behind such discriminatory behaviors.

This study examines the increase in ageism during the Covid-19 pandemic based on major theories and current research. To this end, this study first defines the concepts of "discrimination" and "ageism" in detail. The phenomenon of ageism, which is a form of discrimination, is discussed. Pandemic-related ageism is then discussed within the framework of basic theoretical approaches, including terror management, attribution, psychoanalytic, social identity, and framing theories, as well as the evolutionary perspective. Finally, recommendations to prevent ageism related to the pandemic and in general are made.

Being aware of human tendencies is a good starting point to fight problematic behaviors such as ageism. Therefore, it is important to understand age-related prejudices and how relevant processes act in extraordinary conditions, such as a pandemic, and to develop appropriate, functional, forward-looking measures, as required. It should not be forgotten that age groups are also heterogeneous like every other group, so individual differences within these groups should not be ignored. It is important to recognize not only negative and hostile ageism but also benevolent ageism. Increasing public awareness of and sensitivity to all types of discrimination, particularly ageism, 
is of prime importance. Therefore, it is necessary to behave respectfully toward older people and to avoid the use of patronizing and derogatory speech.

In this review, in light of recent research, it was revealed that there is a significant increase in the number of cases of discrimination during the Covid-19 pandemic. Ageism has spread at the same rate as the epidemic, with restrictions being imposed on individuals of certain age groups. Considering the negative consequences documented in scientific findings, it is clear that this is an emergency that needs to be handled with a multidisciplinary approach.

\section{GíRiş}

Illk olarak 2019 yılının Aralık ayında Çin'de görülen yeni tip coronavirüs Covid-19 (CoronaVirus Disease 2019), 30 Ocak 2020'de (World Health Organization [WHO], 2020e) 'uluslararası önem arz eden halk sağlığı acil durumu' olarak ve 11 Mart 2020'de'pandemi' olarak ilan edilmiştir (WHO, 2020d). Küresel salgın hızla yayılmaya devam etmiş, 20 Aralık 2020 itibarıyle 216 ülkede toplam 74.879 .038 vaka sayısına ulaşılmış ve 1.676.236 kişinin ölümüne yol açmıştır (WHO, 2020c).

Pandemi sadece sağlık sorunlarına ve ölümlere değil, aynı zamanda dünya genelinde ekonomik, eğitimsel, psikolojik ve toplumsal sorunlara yol açmıştır. Bunların yanında tüm dünyada şiddet olaylarını tetikleyen "ayrımcılık" eğiliminin de tırmanışa geçtiği, bu durumun adeta virüsten daha hızlı yayılan ayrı bir salgına dönüştüğü gözlenmektedir (Previtali, Keskinen, Niska, \& Nikander, 2020). Bu tür kriz dönemlerinde ortaya çıkan ayrımcılığın, oldukça kalıcı, değişime dirençli sorunlardan biri olageldiği bilinmektedir (Oldstone, 1998; Williams, Gonzalez-Medina, \& Le, 2011).

Geçmiş salgınlarda olduğu gibi, yeni pandemide de belirli gruplar daha çok ayrımclığa maruz kalmış, yeni tip coronavirüs 'Wuhan virüsü' ve 'Çin virüsü' gibi adlarla anılmaya başlanmıştır (Human Rights Watch, 2020). Bu durum özellikle azınlık gruplarına yönelik ırkçı saldırıları ve yabancı düşmanlığını artırmıştır (Kim, 2020; Nature, 2020). Çinıde Afrikalılar ikinci dalgaya neden olabilecekleri gerekçesiyle ayrımcılığın hedefi haline gelmiştir (Burke, Akinwotu, \& Kuo, 2020). Hindistan'da İslamofobik sosyal medya paylaşımları artmıştır (Perrigo, 2020). Birleşmiş Milletler Genel Sekreteri Guterres (2020a) salgınının hızla 'bir insan hakları krizi' haline geldiğini vurgulamıştır. "Covid-19'un bir 
sonucu olarak nefret söylemi, damgalanma ve yabancı düşsmanlığı artmaktadır" (Guterres, 2020b).

Uluslararası insan hakları hukukuna göre, her insan mümkün olan en yüksek sağlık standardına sahip olma hakkına sahiptir. Hükümetlerin, halk sağlığı tehditleri söz konusu olduğunda, insan haklarını göz ardı etmeden, halk sağlığına yönelik her türlü tehdidi önleme ve intiyacı olanlara ayrım yapmaksızın, adil bir şekilde tıbbi bakım sağlama yükümlülüğü vardır (Human Rights Watch, 2020). Büyük oranda bu sorumluluğa dayandırılan, 65 yaş ve üstü (farklı ülkelerde 60, 70, 75 yaş) bireyleri konuma amaçı̆ı uygulamalar, beklenmedik bir şekilde bu bireyleri ayrımcılığın hedefi konumuna getirmiştir. Covid-19, etnik kökene dayalı ayrımcılığın yanında, ileri yaştaki bireylere yönelik ayrımcılığı da gündeme taşımış, koruma amaçlı alındığı vurgulanan önlemlerin yaşçılığı tırmanışa geçirdiği görülmüştür (Ayalon et al., 2020; Panagiotis et al., 2020).

Belirli bir yaş grubunu daha 'yaralanabilir' olarak etiketlemek hastalığın yayılmasını önleme çabalarını da sabote etmektedir (Mak et al., 2006). Belirli gruplara yönelik ayrımcı ve önyargılı söylemler, diğer gruplara ilişkin gerçek dışı olumlu önyargılara neden olabilir. Belirli grupların yüksek risk altında olarak hedef gösterilmesi, diğerlerinin risk altında olmadıkları yanılgısına kapılmalarına yol açabilir. Böylece, bireyler belirli bir grubun üyelerini dışlarken, diğer grupların üyeleriyle tereddüt etmeden iletişim halinde olurlar; bir grup korunma altına alınırken diğer grup kaygısızca önlem önerilerine uymayı bırakabilir. Covid-19 döneminde yaşçılık bu durumun tipik bir örneği olarak karşımıza çıkmaktadır. İleri yetişkinlik dönemindeki bireylerin risk alında olmalarının altının çizilmesi, diğer yaş gruplarındaki bireylerin kendilerini gerçekte olduğundan daha az risk altında görmelerine, bu da artan kural inlallerine, daha genç yaş gruplarındaki bireylerin bu algının etkisiyle hem kendilerini hem de aile üyelerini tehlikeye atacak davranışlarda bulunmalarına neden olmuştur.

Ayrımcılığa maruz kalmanın hem psikolojik hem de fizyolojik sağlık üzerinde birçok olumsuz etkisi olduğu bilinmektedir (Jetten, Reicher, Haslam, \& Cruwys, 2020). Algılanan ayrımcılık ile psikolojik gönenç arasında olumsuz bir ilişki vardır (Schmitt, Branscombe, Postmes, \& Garcia, 2014); düşük yaşam doyumu, düşük benlik saygısı, depresyon ve kaygı bozukluğu gibi yaygın psikolojik sorunlarla yakından ilişkilidir.

Ayrımcılık gibi bireysel ve toplumsal yansımaları son derece can yakıcı olan sorunlarla mücadele ederken, öncelikle, bu sürecin altında yatan temel güdülenmeyi kavramak 
büyük önem taşımaktadır. Bu nedenle, Covid-19 ile ilgili ayrımcılık ve yaşçııkla mücadelede, bu süreçle ilgili temel kavramları, özellikle bu tür kriz dönemlerinde artış gösteren bu eğilimi tetikleyen güdülenmeyi ve temel etmenleri anlamak gerekmektedir. Dolayısıyla, salgınla savaşırken sadece virüsün yayılımını önleme çabaları yeterli değildir. Aynı zamanda bu olağanüstü durumun bireysel ve toplumsal boyutta yarattığı anlık ve ileriye dönük olumsuz etkileri de gözetmek, toplumun dokusunu bozabilecek kadar güçlü olumsuz etkileri olan ayrımcılıkla mücadele etmek de son derece önemlidir. Bu nedenle, hem Covid-19 özelinde hem de genel olarak bulaşıcı hastalıklara bağlı ayrımcılık konusunda araştırma ve çalışmalar yürütmek büyük önem arz etmektedir.

Bu makalede Covid-19 pandemisi döneminde artan yaşçılığı, güncel araştırmalar ve temel kuramsal yaklaşımlar ışığında kavramak, nedenlerini, aynı zamanda toplumsal ve bireysel etkilerini irdelemek hedeflenmektedir. Bu amaçla, öncelikle ayrımcılık kavramı, ilgili temel kavram ve süreçler kısaca ele alınacaktır. Ardından temel kuramsal yaklaşımlar ve güncel bulgular ışığında yaşçııı üzerinde durulacak ve daha sonra Covid-19 döneminde yaşanan bu özgül ayrımcılık türünün ortaya çıkıs şekilleri, medyadaki yansımaları, etkileri güncel araştırma bulguları çerçevesinde irdelenecektir. Son olarak da bu durumla mücadele etme yolunda izlenebilecek yollar üzerine bazı önerilerde bulunulacaktır. Güncel önemi son derece yüksek olan bir toplumsal/evrensel sorun üzerine yazılmış olan bu çalışma, konuyu çok yönlü bir yaklaşımla ele alma, özellikle psikoloji ve iletişime dayalı temel kavramları açıklayarak kuramsal bir tartışma sunma niteliği açısından özgündür. Yaşçıı̆ın hem evrensel hem de kültüre özgü bir boyutta ele alınışı, pandemi dönemindeki yaşçılığı en güncel veriler ve araştırma bulguları ışığında irdeleyip tartışıyor olması da bu çalışmayı özgün kılan niteliklerdendir.

\section{Yaşçılık; Tanımı, İlgili Kavramlar ve Kuramsal Yaklaşımlar}

Ayrımcılık (discrimination), belirli sosyal grupların üyelerine, sadece'o grubun üyesi oldukları için', çoğunlukla adaletsizce ve küçük düşürücü bir şekilde farklı davranmaktır (Whitley \& Kite, 2009). Ayrımcı eylemler sözel ya da sözsüz olarak birçok farklı formda vücut bulabilir. Dışlama, lakap takma, tehdit etme, düşmanca mesajlar gönderme, mimik ve jestlerle aşağılama, küçümseyici şakalar yapma ve fiziksel şiddet uygulama gibi birçok yolla kendini gösterebilir. Ayrımcılık sergilenme şeklinden bağımsız olarak, her durumda kurbanın kendini yalnız, yalıtılmış, reddedilmiş, görmezden gelinmiş ve değersiz hissetmesine yol açmakta; bir tür cezalandırıma, tacize uğrama, günah keçisi ilan edilme gibi algılanmaktadır. 
Önyargı (prejudice) ve kalıpyargı (stereotype) ayrımcılıkla yakından ilişkili kavramlardır. Sosyal sınıflandırma sürecinin doğurgusu olan bu üç kavram arasındaki ilişkiyi kısaca; önyargının genel bir tutum olduğunu ve daha çok duygusal bir içeriğe sahip olduğunu (yaşlılardan pek hoşlanmam), kalıpyargının bilişsel (yaşlı insanlar huysuzdur) ve ayrımcılığın da davranışsal (benden uzak olsunlar, şikâyet dinlemek istemiyorum) birer boyut olduğunu vurgulayarak özetlemek mümkündür (Eagly \& Chaiken, 1998). Kalıpyargılar belirli bir gruba ve üyelerine ilişkin, aşırı genellenmiş inançlardır. Bu kavramı literatüre kazandıran Lippman (1922), kalıpyargıyı belirli bir grubu ve üyelerini tanımlayan 'zihnimizdeki resimler' olarak anlatır. Bu resimler çoğunlukla sosyal gruplara yönelik yanlı, katı, yüzeysel temsillerdir (Stroebe \& Insko, 1989).

Önyargılar kimi zaman deneyime dayalı ve birikimli bir yapı sergilerken, bazen de aniden, içinde bulunulan koşulların ve/veya ipuçlarının tetiklemesiyle belirip ayrımcılıkla sonuçlanabilmektedir. Bu koşullar çoğunlukla bireysel, toplumsal, ekonomik, sağlığa dayalı etmenlerle ilişkilidir ve içlerinde önyargıyı tetikleyip ayrımcı eylemleri harekete geçirme olasılığı en yüksek olanlarııın doğal afet ve salgın gibi beklenmedik, olağanüstü durumlar olduğu söylenebilir (Demirtaş-Madran, 2020).

Yaş̧̧ılık (yaşa dayalı ayrımclık)"bireyleri kronolojik yaşlarını temel alarak sınıflandırmak, bu sınıflandırma ışı̆ıında damgalamak, etiketlemek, kalıpyargılamak ve tüm bunların sonucu olarak da ayrımcı davranmak"şeklinde tanımlanabilir (Butler, 1969; Çayır, 2012; 2018; Duben, 2018; İnceoğlu, 2021).

Kavramı ilk kez kaleme alan Butler (1969), yaş̧̧ılıkla, ilerlemiş yaşları nedeniyle insanlara kötü ve haksız muamele edilmesi sürecini kastetmiştir. Ona göre yaşçılığın altında ihtiyarlama, hastalanma ve elden ayaktan düşmeye yönelik bastııılmış kaygıların yol açtığı bir rahatsızlık; aynı zamanda ölüm, güçsüzleşme, işeyaramaz bir bireye dönüşme korkusu yatmaktadır.

Yaşçılık, belirli bir yaş grubundaki bireylerin birbirlerine benzerliğini ('hepsi aynı') abartma ve grup-içi çeşitliliği reddetme eğilimidir. Böylece aynı yaş grubundaki bireylerin değişmez şekilde benzer bir dış görünüşe, davranış örüntülerine ve düşünce yapısına sahip olduklarına inanılır. Her yaş grubundaki birey, ancak en çok ileri yaştaki bireyler ve çocuklar/gençler yaşları nedeniyle ayrımcılığa maruz kalmaktadırlar (Kydd \& Fleming, 2015). Etkisi, sonuçları ve yaygınlığı dikkate alındığında yaşçıık denince akla öncelikle ileri yaştaki bireylere yönelik ayrımcılığın geldiği görülmektedir (Sargeant, 2011). 
Irkçılık ve cinsiyetçilik kadar çok araştırmaya konu olmamışsa da, yaşçılık da son derece yaygın bir ayrımcılık türüdür (Çayır, 2012). Ancak diğer ayrımcılık türlerinden belirli farklılıklar göstermektedir. İlki 'yaş' kategorisinin değişmez olmayışıdır; herkes sırayla tüm yaş gruplarının üyesi olur, gençler de birer ileri yetişkin adayıdır. Dolayısıyla yaşçılık yapan bireyler, bir gün (eğer şanslılarsa) üyesi olacakları bir grubun üyelerine ilişkin önyargı geliştirmektedirler. İkincisi, yaşçılık ırkçılık, cinsiyetçilik gibi toplumsal farkındalığın yüksek olduğu, yaygın tepki gören bir ayrımcılık türü değildir (Iversen, Larsen, \& Solem, 2009).

Kimin genç kimin yaşlı olarak değerlendirildiği bireye, topluma, kültüre, çağa göre değişse de, zihnimizde genel bir'yaşlı've 'genç'temsili bulunmaktadır. Birleşmiş Milletler 60 (kimi zaman 65 yaş) ve üstünü yaşlı olarak gruplandırırken, Dünya Sağlık Örgütü (WHO, 2020a) 65 yaşı yaşlılık (elderly) ve 80 yaşı ileri yaşlılık (oldest-old) olarak sınıflandırmayı önermektedir. Bu tür sınıflandırmalar sağladıkları bazı kolaylıkların yanında bize ağır bedeller de ödetmektedir; en büyük bedel de, bu bağlamda, yaşçılık olarak karşımıza çıkmaktadır.

Modern toplumlarda, kronolojik yaşın beraberinde getirdiği değişimler sadece tıbbi ve fiziksel değişim ile sınırlı kalmamakta, aynı zamanda belirgin bir 'toplumsal güç ve saygınlık kaybı' da gündeme gelmektedir. Geçmişte bilge olarak görülen ileri yaşlı bireyler, bugün birçok olumsuz kalıpyargı ile tanımlanır olmuştur. Sosyolojik olarak ele alındığında, bu değişim, büyük oranda artan sanayileşme ve kentleşmenin, aktif üretim sürecinin dışında kalmanın, modernleşmenin, tüketime dayalı yaşamın toplumsal değerler üzerinde yarattığı etkinin bir sonucu olarak değerlendirilmektedir (Yaşar \& Avcı, 2020).

Araştırmalara göre insanlar bir bireyin yaşlanıp yaşlanmadığına'zihinsel yetilerinde azalma/bunama' veya 'işe yaramaz' olma gibi ölçütlere bakarak karar verdiklerini belirtmektedirler (Whitley \& Kite, 2009). Çoğu insan kronolojik yaşı ilerlese de kendini 'yaşı' olarak adlandırmaktan kaçınmaktadır, bunun altında da büyük oranda yaygın yaşçı kalıpyargılar yatmaktadır (Palmore, 1999). Bacon'un (as cited in Whitley \& Kite, 2009, p. 500) "Asla yaşlı bir adam olmayacağım. Bana göre yaşlılık her zaman benden 15 yaş uzaktadır" sözü bu duruma güzel bir örnektir.

İleri yetişkinlerle kurulan iletişim biçimi, yaşçılığın en belirgin işaretlerinden biridir (Whitley \& Kite, 2009). Genç yetişkinlerin bu yaş grubundaki bireylerle konuşurken 'üstünlük taslayan konuşma biçimine (patronizing speech)' başvurdukları ve konuşma 
stratejilerini yaşçı kalıpyargılar rehberliğinde belirledikleri görülmektedir (Ryan, Giles, Bartolucci, \& Henwood, 1986). Bu iletişim biçimi, daha yavaş bir hızda, daha yüksek perdeden, daha kısa süreli konuşmayı, daha sınırlı bir kelime dağarcığı kullanma yoluyla daha anlaşılır ve basit bir dil seçimini, tane tane ve tekrarlı bir anlatımı, otoriter ve/veya abartılı, bu bağlamda küçümseyici/aşağılayıcı bir duygusal ton kullanımını içermektedir. Bu konuşma türünün abartılı bir örneği'bebek konuşması'kullanma eğilimidir (Harwood, Giles, \& Ryan, 1995).

Öte yandan, 'Yaş yetmiş iş bitmiş̧, 'Ununu elemiş, eleğini asmış', 'Kurt kocayınca köpeğin maskarası olur' gibi söylemler kültürümüzde ileri yaştaki bireylere yönelik ayrımcılığın belgeleridir. Illeri yaştaki bireylerin, medyada ve hatta ders kitaplarında bile üretmeyen, topluma katkı sunmayan kişiler olarak resmedildikleri görülmektedir. Unutulmamalıdır ki, insan hakları yaş, cinsiyet, ırk, din, dil, gelir düzeyi ve diğer tüm sosyal sınıflandırma ölçütlerinden bağımsızdır.

\section{Pandemi Dönemlerinde Ayrımcılık; İlgili Kuramsal Yaklaşımlar ve Yaşçılığa Özgü Çıkarımlar}

Pandemi dönemleri, özellikle 'günah keçisi' belirlemenin kolay olduğu durumlarda ayrımcılık için elverişli bir zemin hazırlamaktadır (Cogan \& Herek, 1998). Bu durum, hastalık belirgin belirtilere sahipse, hızlı yayılıyorsa ve ölümcülse daha da artmaktadır. Covid-19 salgının bu niteliklerin tümüne sahip oluşu, bu süreçte yaşçlık başta olmak üzere ayrımcılığın neden bu denli arttığını anlamayı kolaylaştırmaktadır.

H1N1 salgını sırasında, evsiz bireylerin ve eşcinsellerin ayrımcılıkla karşı karşıya kaldıkları (Goodwin, Haque, Neto, \& Myers, 2009); HIV/AIDS ve tüberküloz ile damgalanan bireylerin, sağlık hizmetleri ve istihdam açısından dezavantajlı duruma düştükleri, sosyal çevrelerinden kötü muamele gördükleri bilinmektedir. SARS, sifiliz ve genital herpes için de benzeri bir durum söz konusu olmuştur (Busza, 2001; Mak et al., 2006). İlk Covid-19 vakalarının bildirilmesinden bu yana da tüm dünyada, Çin halkına, Asya kökenli bireylere, hastalık belirtisi gösterenlere ve hatta sağlık çalışanlarına yönelik artan bir dışlama ve damgalama gözlemlenmiştir (Demirtaş-Madran, 2020).

Barrett ve Brown'a göre (2008) 'ayrımcılık salgını' pandemiden daha büyük bir hızla dünyanın her yerine yayılabilir, çok sayıda tıbbi, sosyal, politik ve ekonomik soruna neden olabilir. Bu nedenle, bu süreçte ayrımcılık eğiliminde artışa yol açan motivasyonu 
anlamak önemlidir. Bu alt başlıkta, söz konusu dinamikler temel kuramsal yaklaşımlar ışığında ve yaşçıııla ilişkisi temelinde ele alınarak tartışılacaktır.

Psikanalitik Kuram, ayrımcılığı sosyal (afetler, hastalıklar, kıtlık) ve bireysel engellenmeler sonucunda beliren bir'yer değiştirmiş saldırganlık' olarak ele almaktadır. Bu yaklaşıma göre, ayrımcı eylemlerin benlik savunucu bir işlevi vardır (Whitley \& Kite, 2009). Kaygı arttıkça ötekileştirme ve öteki olarak adlandırılan grubun tüm üyelerini 'kötü' olarak etiketleme eğilimi de artmaktadır (Joffe, 1999). Covid-19 pandemisinin hem sağlık, hem de sosyal yaşam ve özgürlükler açısından çok büyük bir engellenme kaynağı olduğu açıktır. Dolayısıyla, özellikle azınlık gruplarına yönelik saldırganlık düzeyine ulaşan ayrımcı eylemlerin artışını yorumlamak güç olmayacaktır. Klasik 'engellenme-saldırganlık hipotezi' (Dollard, Miller, Doob, Mowrer, \& Sears, 1939), Allport'un (1954) Günah Keçisi Kuramı (Scapegoat Theory) gibi çarpıcı kuramların çıkış noktası olmuş; ten rengi, yaş gibi 'görünür' farklılıkların ayrımcılık için birer günah keçisi belirlemenin yolunu açtığı öne sürülmüştür. Birçok güncel araştırma (Devakumar, Bhopal, \& Shannon, 2020; He, He, Zhou, Nie, \& He, 2020; Liu, Finch, Brenneke, Thomas, \& Le, 2020; Perrigo, 2020) bu durumu belgelemektedir.

Evrimsel Yaklaşıma göre ayrımcılık kökleri avcı-toplayıcı toplumlara dayanan, hayatta kalmak açısından son derece işlevsel olan, kaçınılmaz ve değiştirilmesi güç bir eğilimdir (Buss \& Kenrick, 1998; Faulkner, Schaller, Park, \& Duncan, 2004; Levy \& Hughes, 2009). Ayrımcılık, salgın dönemlerinde hayatta kalmak ve soyunu sürdürmek amacıyla başvurulan bir tür savunmadır (Faulkner et al., 2004; Gilles et al., 2013). Pandemi döneminde artan ayrımcılığı bu yaklaşımla açıklamak da mümkündür. Tabri, Hollingshead, \&Wohl (2020), Amerika'da Covid-19'un neden olduğu varoluşsal tehdidin Çinlilere ve benzer kökenden gelenlere yönelik önyargıları yordadığı bulgusuna ulaşmışlardır.

Terör Yönetimi Kuramı (Terror Management Theory) (Greenberg, Pyszczynski, \& Solomon, 1986), insanların yaşadığı en büyük dehşetin ölümlü oldukları gerçeğiyle yüzleştiklerinde ortaya çıktığını savunur. Kurama göre salgın dönemlerinde 'ölümlülüğün belirginleşmesi (mortality salience)' dehşet duygusunu artırır, bireyler benlik saygılarına ve kültürel değerlerine sarılarak bu terörle başetmeye çalışılar. 'Ölümlü olduğumuzu hatırlatan' bireylere yönelik ayrımcılık da aynı amaca hizmet eder (Greenberg, Landau, Kosloff, \& Solomon, 2009, p. 309). Yaş almış bireyler daha genç yaştaki bireyler için 'kaçınılmaz kaderlerinin birer temsilidir; azalan güzellik, sağlık, duygular ve nihayetinde ölüm' (Greenberg, Schimel, \& Martens, 2002, p. 29). Covid-19 salgınının hızla artan 
ölümlerin de etkisiyle'ölümlülük belirginliği'ni harekete geçirerek ayrımcılığı tetiklediği söylenebilir (Courtney, Goldenberg, \& Boyd, 2020). Ölüm korkusuyla başetmeye çalışan birey, ölümlülüğü çağrıştıran günah keçilerini bulup onları değersizleştirir (Becker, 1975). Pandemi sırasında artan yaşçllık (Ayalon et al., 2020; Brooke \& Jackson, 2020; Rahman \& Jahan, 2020), ileri yaştaki bireylerin gençlere 'kendi ölümlülüklerini hatırlatmaları' ile açıklanabilir. Yaşçılık "yüzleşmekten korktuğumuz gelecekteki benliğimize yönelik önyargımızdır" (Nelson, 2016, p. 347).

Yükleme Kuramına (Attribution Theory) dayanan 'adil dünya denencesi (just-world hypothesis)'ne göre (Lerner, 1980) insanlar dünyanın adil olduğuna ve herkesin hak ettiğini aldığına inanma eğilimi gösterirler. Talihsiz olaylar yaşayan, hasta, acı çeken bireyleri içinde bulundukları durumdan sorumlu tutmak, yönetilebilir ve öngörülebilir bir dünyada yaşama arzusunun bir sonucu olan bu eğilimin doğurgusudur (Lerner, 1980). Dezavantajlı gruplar, yoksullar, hastalar ve depremzedeler adil bir dünyaya olan inancı tehdit eder, bu sorunları kişinin özelliklerine ve/veya hatalarına atfetme yönündeki bu işlevsel inanca sarılmamıza yol açar. Herkesin 'ektiğini biçtiğine' inanmak, haketmediğimiz takdirde aynı talihsizliklerin başımıza gelmeyeceğini düşünüp rahatlamamızı sağlamaktadır (Greenberg et al., 2009). Adil bir dünyada herkes hak ettiğini alır ve sadece'kötü insanların başına kötü şeyler' gelir (Burger, 1992; Greenberg et al., 2009; Jost \& Van der Toorn, 2011). Covid-19 salgını sırasında birçok kişi salgının başlangııını ve yayıımasını bu şekilde değerlendirmiş, hastalığın yayıımasının alışı madık beslenme alışkanlıklarından kaynaklandığına inanılmış ve bu insanların başlarına gelenleri hak ettiklerine ilişkin birçok görüş öne sürülmüştür. Tanrı'nın bazı insanları ahlaki zayıflıkları nedeniyle bu şekilde cezalandırdığını, Doğa Ananın kendisine kötü davrananları cezalandırdığını savunanlar olmuştur. Crandall ve arkadaşlarının (2001) 'ilişskilendirme-Değer Modeli' ne göre, önyargı ve ayrımcılık, azınlık gruplarını çoğunluk grubunun değerlerine zıt özelliklere sahip olarak görmenin bir sonucudur. Bu nedenle, obez olarak sınıflandırılan bireyleri (altında başka bir hastalığın yatması nedeniyle bu durumda olanları dahi) tembel ve zayıf iradeli bireyler olarak görmek, AIDS hastalarını çok eşli ve ahlaksız kabul etmek oldukça yaygındır (Joffe \& Staerklé, 2007). Pandemi döneminde ileri yaşlı bireylerin'yeterince yaşadıklarını' düşünerek yaralanabilirliklerini olağanlaştırmak, 'güçsüz' ve'hasta' oldukları için onları daha çok risk altında görmek de benzer bir rahatlama sağlamaktadır.

Sosyal Kimlik Kuramı da (Tajfel, 1978; Turner, Hogg, Oakes, Reicher, \&Wetherell, 1987) salgın dönemindeki dinamikleri anlamada oldukça yol göstericidir. Sosyal kimlik ve grup üyeliği, Covid-19 salgını deneyimini hem psikolojik hem de normatif olarak öngören 
çok önemli faktörlerdir. Bu süreçte, insanlar özellikle medyadan edindikleri bilgiler doğrultusunda 'sosyal karşılaştırma' yapma yoluna gitmektediler (Jetten et al., 2018; Jetten et al., 2020). Bu karşılaştırma, gruplarının (ülke, şehir, yaş grubu) durumuna ilişkin bir değerlendirme yapmak için olduğu gibi aslında kendi durumlarına ilişkin bir çıkarsama yapmak için de kullanılmaktadır. Birey olarak, sağlık durumumuzu, cinsiyetimizi, kan grubumuzu, kronik hastalıklarımızı dikkate alarak içinde bulunduğumuz riski algılamaya çalışmakta, çeşitli savunma yollarıyla da bu karşılaş̧ırmayı hem grubumuz hem de kendimiz lehine yanlı olarak gerçekleştirme eğilimi içine girmekteyiz. Bu karşılaştırmadan karlı çıkmayı başarmanın yollarından biri de'aşağıya doğru karşılaştırma'yapmak, kendi grubumuzu daha kötü durumdaki gruplarla karşılaştırma yoluna gitmektir (bkz. Festinger, 1954). Bu sosyal karşılaştırma, Sosyal Kimlik Kuramında vurgulanan'iç-grup kayırmacılığını (in-group favouritism)' içerir (Fiske, 2005). Covid-19 sürecinde de bu eğilimin, kendi gruplarını daha üstün gören bireylerin diğer grupları kendilerinden daha az değerli görmelerine yol açtığı söylenebilir (Assche, Politi, Van Dessel, \& Phalet, 2020; Green et al., 2010; Joffe, Washer, \& Solberg, 2011). Böylelikle, belirli gruplara karşı ayrımcılık yapanlar kendi sosyal kimliklerini ve özgüvenlerini güçlendirmeyi amaçlamaktadır ki bu da hastalığa yakalanma ve/veya ölüm riskine yönelik algıyla ve bunun yarattığı kaygıyla başa çıkmanın bir yoludur. Covid-19 dönemindeki ileri yaştaki bireyleri aşırı genelleme yoluyla kırılgan ve risk altında görme durumunu da sosyal karşılaştırmayla açıklamak mümkündür. Dünyaya 'yaşlılar've'yaşlı olmayanlar' ayrımıyla bakmak ve bu iki grup arasında iç-grup kayırmacılığı yaparak bir sosyal karşılaştırma gerçekleştirmek, gençlerin kendilerini daha güvende hissederek hastalık ve ölüm korkusuyla başetmelerini kolaylaştırmaktadır.

Pandemiler, özellikle nedeni belirli bir birey ya da gruba atfedilebilir, belirgin belirtilere sahip ve yüksek düzeyde bulaşıcı/ölümcül olduğunda ayrımcılık eylemlerine zemin hazırlamaktadır (Cogan \& Herek, 1998). Bu tür krizlerde artan ayrımcılık pandemi önlemlerine uymayanlara uygulanan yaptırımlara da yansımaktadır. Assche ve arkadaşları (2020), Covid-19 ile ilgili önlemlere uymayanlara yönelik yaptırımları savunan bireylerin, bu uygulamaları kendi grup üyelerinden çok dış gruplar için desteklediklerini ortaya koymuşlardır. Diğer bir deyişle, araştırmaya katılanlar, pandemi kurallarına uymamaları halinde kendi grup üyelerine değil,'öteki' diye ayırdıkları dış grup üyelerine katı yaptırımlar uygulanması gerektiğini savunmuşlardır. 


\section{Covid-19 Döneminde Yaşçılık; Güncel Bulgu ve Tartışmalar}

Covid-19 salgını tüm dünyada günlük yaşamı benzeri görülmemiş bir şekilde etkilemiştir ve etkilemeyi de sürdürmektedir. Sağlık otoriteleri, doğrulanmış vakaların ve virus nedeniyle ölümlerin yüksek bir yüzdesini ileri yaştaki yetişkinlerin oluşturduğunu bildirmektedir (WHO, 2020b). Dünya Sağlık Örgütü'ne göre (WHO, 2020b), ileri yaştaki bireyler, yaşlanmayla ilişkili fizyolojik değişiklikler, zayıflamış bağışıklık sistemi, artan kronik hastalıklar gibi çeşitli risk faktörlerinin bir arada bulunması nedeniyle Covid-19 kaynaklı sağlık sorunları yaşama ve yaşamını yitirme açısından daha büyük bir risk altındadır. Diğer genç yaştaki bireylerin de risk altında olmalarına rağmen medyanın da düzenlemelerin de merkezinde daha çok ileri yaştaki bireylerin olduğu görülmektedir (Previtali et al., 2020). Koruyucu olma vurgusuyla uygulanan politikalar bu yaş grubuna 'patronluk, üstünlük taslama' olarak değerlendirilmeye başlanmış ve virüsün sadece bu yaş grubunu etkileyeceği yönünde yanlış bir algıyı beraberinde getirmiştir. Bu süreçte, ileri yaştaki bireylerin açıkça yanlış ve yanlı temsil edilmekte, 'küçümsenmekte' olduğu görülmektedir (Fraser et al., 2020).

Kronolojik yaşın bir 'aşırı genelleme' ölçütüne dönüştürülmesine dayalı olan bu politikalar, ileri yaştaki bireyleri değersizleştirme, olduklarından daha güçsüz ve çaresiz olarak etiketleme ve yaş grupları arasındaki farklılıkları abartma eğilimini beraberinde getirmektedir. Kronolojik yaş, bu politikaların temeli olarak kullanılsa da, hangi yaş sınırının eşik olarak kullanılacağına ilişkin uluslararası bir anlaşma $(60,65,70$ veya 75 gibi) dahi yoktur (Previtali et al., 2020). Bu eğilim, yaşla kronik hastalıklar arasındaki ilişkiye temellendirilse de, belirli bir yaşın üzerinde olmak savunmasız ve güçsüz olmak anlamına gelmemektedir. Bu, gerekçesi her ne olursa olsun açık bir şekilde bir insan hakları ihlali olarak değerlendirilmektedir (OHCHR, 2020).

Öte yandan, yaş̧̧ılık sadece 'olumsuz' ve 'düşmanca' ayrımcılık olarak karşımıza çıkmamakta, 'şefkatli yaşçlık (compassionate ageism)'ta da büyük bir artış gözlenmektedir (Vervaecke \& Meisner, 2020). Kite, Stockdale, Whitley ve Johnson (2005) gerçekleştirdikleri meta-analiz çalışmasında, bu yaş dönemindeki bireylerin daha genç yaştaki bireylerden daha az yetkin, özgüvenli, özerk ve güçlü; ancak aynı zamanda sıcak, samimi ve nazik olarak değerlendirildikleri sonucuna varmışlardır. Kalıpyargı Içeriği Modeli (stereotype content theory), kalıpyargıların olumlu ve olumsuz olarak ikiye ayrılarak incelenmesi geleneğinin gerçeği yansıtmadığını, kalıpyargıların belirli bir gruba ve üyelerine ilişkin iki ayrı temel boyutta (sıcaklık ve yeterlilik) gerçekleştirilen değerlendirmeler sonucunda 
oluşan bir tür karışım olduğunu öne sürmektedir (Fiske, Cuddy, Glick, \& Xu, 2002). Kronolojik yaşı ileri bireyleri 'güçsüz ama mükemmel', 'ihtiyar ama çok tatlı' olarak değerlendirme eğilimi oldukça yaygındır. Çelişik duygulu yaş̧̧ılık (benevolent ageism) olarak adlandırılan bu durum 'aşırı' yardım etme ve acıma eğilimini beraberinde getirmekte, kurban konumundaki bireylerin 'işeyaramazlık've'çaresizlik' hissetmelerine yol açmaktadır (Bugental \& Hehman, 2007). Bu çelişik kalıpyargılar paternalist bir eğilimle sonuçlanmakta, güçlü ve baskın olan grupların daha düşük statüde olarak algılananları koruması ve onlara bakım vermesi gerektiği yönünde bir bakış açısını beraberinde getirmektedir. Bu durum şefkat gösterme, acıma ve belirli koşullar söz konusu olduğunda aşııı duyarlııı gösterme gibi eğilimlerle sonuçlanmaktadır (Fiske et al., 2002).

Covid-19 pandemisinin bu eğilimleri harekete geçirmek için oldukça elverişli bir ortam sunduğu, tüm dünya genelinde ileri yaşı bireylere 'üstünlük taslayan ve acıyan bir yaklaşımla yardım etme' örneklerinin gözlendiği görülmektedir. Bu davranışlar iyi niyetli de olsa, aynı zamanda aşağılayıcı olabilmektedir. Kampanyalarda ve bireysel eylemlerde sıklıkla 'üstünlük taslayan' bir dil kullanıldığı, ileri yaşlı bireylerin muhtaç, çaresiz ve elden ayaktan düşmüş olduklarının altını çizen söylemlere yer verildiği görülmektedir (Vervaecke \& Meisner, 2020). Masum gibi görünen şefkatli yaş̧̧ılığın, sonuçları açısından son derece hasar verici olduğu, benlik saygısı, fiziksel yeterlilik, bilişsel performans, psikolojik iyilik hali ve sosyal katılımda düşüşe yol açtığı ortaya konmuştur. Üstünlük taslayan konuşmaya maruz kalan ileri yaşlı bireylerin bu sürecin etkisiyle bilişsel sorunlar yaşadıkları ve stres hormonlarında artış olduğu görülmüştür (Hehman \& Bugental, 2015).

Konuya etik açıdan yaklaştığımızda, ayrımcılığın kimi zaman adil de olabileceğini görürüz. Plato'nun deyimiyle "farklı muameleyi gerekli kılacak durumlarda eşitlik sergilemek eşitsizliktir" (as cited in Savulescu \& Cameron 2020, p. 718). Bu bakış açısını karantina ve izolasyon sürecine uyarladığımızda, örneğin, yurt dışına seyahat eden bireylerin ülkeye dönüşte karantinaya alınmalarını virüsü yayma olasılıklarının artmış olması nedeniyle haklı bir gerekçeyle uygulanan adil bir ayrım olarak değerlendirebiliriz. Benzer şekilde, pandeminin yayılma hızını azaltmak ve sağlık sisteminin çökmesini önlemek için, bilimsel olarak daha yüksek risk altında olan bireyleri geçici olarak korumaya almak bu bağlamda değerlendirilebilir (Savulescu \& Cameron, 2020). Ancak koruma amacıyla girişilen bu uygulamanın önü alınamaz bir başka salgını, yaşçılığı tetiklediği göz önünde bulundurularak etik bir iletişim dilinin kullanılması konusunda artan bir farkındalığa gereksinim vardır. 
Tüm bunların yanında, bu salgın sırasında kuşaklarası iletişim açısından güzel örneklere de tanıklık edilmiş, kuşaklararası dayanışma artmıştır. Ancak bu örnekler maalesef yaş̧̧ılığın yarattığı hasarın gölgesinde kalmakta, kimi zaman da amacını aşıp şefkatli ayrımcılığa doğru kaymaktadır. Bu süreçte, başta yaşçılık olmak üzere tüm ayrımcılık türleri ile ilgili farkındalığın ve duyarlıı̆ın artııımasının ne denli önemli olduğu gün yüzüne çıkmıştır. Previtali ve arkadaşları (2020, p. 511) yaşananlardan çıkarılacak dersleri şu şekilde sıralamaktadırlar;

a) Yaşcilığın düşünüldüğünden çok daha büyük hasarlar bırakan olumsuz etkileri vardır ve pandemi bu durumun görülme sıklığını daha da artırmıştır.

b) Yaşçılık, yaralanabilir konumdaki bireyleri korumaya yönelik politikaların uygulamaya konmasının ve etkili olmasının önünde büyük bir engeldir.

c) 'Sadece kronolojik yaş' temel alınarak geliştirilen politikalar kuşaklar arası dayanışmayı tehlikeye atmaktadır.

d) Salgın gibi olağanüstü durumlarda, politika yapıcılar ayrımcı ve yaşçı dil kullanımından kaçınmalı, gruplararası ayrışmayı ve kalıpyargıları tetikleyecek söylemlerden uzak durmalıdırlar.

\section{Medyaya Yansıyanlar}

Yeni koronavirüs pandemisi döneminde medyada yer alan haberler ve paylaşımlar insanlarda korku ve paniğe neden olmuş, bu duygusal gerilim belirli gruplara yönelik ayrımcılığı ateşlemiştir (Budhwani \& Sun, 2020; Stechemesser, Wenz, \& Levermann, 2020). Salgınla aynı hızda yayılan bilgi kirliliği ayrımcı bakış açılarının yayılmasına neden olmuştur (Dubey et al., 2020; Fraser et al., 2020).

Sosyal Temsiller Kuramına (Joffe, 1999) göre, salgın gibi krizler dış grupların zihnimizdeki temsillerini etkiler;'biz've'öteki' ayrımı artar. Medya yeni bir tehdidin varlı̆ı̆ın duyurduğunda hızla sosyal temsiller oluşmaya başlamaktadır. Bu temsiller, sadece durumu anlamaya değil, aynı zamanda suçlayacak bir dış-grup bulmaya da hizmet eder (Mayor et al., 2013). Insanlık tarihi boyunca bu gruplararası ayrımı marjinalleştirme ve'sembolik ötekileştirme' (Joffe, 1999) sürecinin birçok örneği görülmüştür. Aynı durum Covid-19 ile ilgili ayrımcılığı ve özellikle yaşçıl̆ı açıklamak için de geçerlidir. 
Çerçeveleme Kuramı (Goffman, 1974) gerçekliğin, belirli noktaların vurgulanması ve/veya bazı boyutların geçiştirilmesi yoluyla farklı şekillerde sunulabileceğini öne sürer. Bir mesajın gücünü ‘ne söylendiği' değil 'nasıl söylendiği' belirler (Lakoff, 2004). Medya, güncel olayları çerçeveleme biçimiyle gündem belirleme gücüne sahiptir. Covid-19 pandemisi sırasında da'yaş'açıkça ayrımcı bir şekilde çerçevelenmiştir (Schnell, McConatha, Magnarelli, \& Fry, 2020). Çerçeveleme önyargı ve kalıpyargıları da şekillendirmektedir (Callaghan \& Schnell, 2001; Terkildsen, Schnell, \& Ling, 1998). Bu güçlü etkinin, önyargı ve ayrımcılığı tetikleme boyutunda en çok kendini gösterdiği boyutsa yaşçılık olmuştur.

Salgının başlamasıyla birlikte tüm dünyada Covid anahtar kelimesi sosyal medyanın ana teması haline gelmiştir ve bu içeriğin yaklaşık olarak yarısı yaşla ilgili (yaş, yaşlanma, geriatrik, yaşlı, yaşlılık) anahtar kelimelerden oluşmaktadır. Bu yüklü içeriğin büyük kısmında ileri yaşlı bireylerin muhtaç, çaresiz, güçsüz ve feda edilebilir olarak temsil edildiği görülmektedir (Schnell et al., 2020). Sosyal medyada nefret söylemi ve saldırgan/ savunmacı dil kullanımı yaklaşık 10 kat artmıştır (Budhwani \& Sun, 2020; Croucher, Nguyen, \& Rahmani, 2020; Stechemesser et al., 2020). İleri yaştaki bireylerin topluma ekonomik anlamda yük olduğu vurgusuyla son derece etik dışı söylemler ortaya çıkmıştır (Guttman \& Lev, 2021). Özellikle Amerika'da bu dönemdeki yaşçılık'\#boomerRemover' ve'\#grandmakiller' etiketleriyle yeni bir seviyeye ulaşmıştır. Jimenez-Sotomayor, GomezMoreno, \& Soto-Perez-De-Celis (2020), pandemi sürecinde ileri yaşlı bireylerle ilgili Twitter paylaşımlarını incelemiş, çoğunun bu yaş grubundaki bireylerin yaşamını daha değersiz bulan, küçümseyici nitelikte olduğunu ortaya koymuşlardır. Ülkemizde de benzer bir durum söz konusu olmuştur ve olmaktadır. Yaşar ve Avcı (2020) Türkiye'de Covid-19 döneminde ileri yaşıı bireylerle ilgili çevrim içi haberleri incelemiş; kısıtlamalara uymayıp dışarı çıkan ileri yaşlı bireylerin ayrımcılığa uğrayarak azarlanma, suçlanma ve alay edilmeye maruz kaldıklarını ortaya koymuşlardır.

Türkiye'de de salgının yaşçı etkilerini ele alan birçok araştırma yürütülmüş (Demir, 2020; Yaşar \& Avcı, 2020), kitaplar yazılmıştır (Giritli-İnceoğlu, 2021; Giritli-İnceoğlu \& Çoban, 2021). Yaşar ve Avcı (2020) Türkiye'de Covid-19 döneminde ileri yaşlı bireylerle ilgili çevrim içi haberleri incelemiş; kısıtlamalara uymayıp dışarı çıkan ileri yaşı bireylerin ayrımcılığa uğrayarak azarlanma, suçlanma ve alay edilmeye maruz kaldıklarını ortaya koymuşlardır. Bu süreç yaşçılığı ülkemizde daha 'görünür' kılmış, kısıtlama dönemlerinde sokağa çıkan ileri yaşlı bireylerin üzerine balkonlardan su döküldüğü, balık ağı atıldığı, 'ceza keserim' gibi şakalarla polismiş gibi davranılarak alay edildiği görülmüştür. Bu yaş 
grubundaki bireyler sosyal medyada ötekileştirilerek karikatürize edilmişlerdir (Giritliİnceoğlu, 2020). Tuna Uysal ve Tan Eren (2020), bu süreçte yapılan Twitter paylaşımlarını inceledikleri çalışmaları sonucunda, bu yaş grubundaki bireylerin alay, küçümsenme, aşağılanma ve hakarete uğradıklarını, nefret söylemlerine maruz kaldıklarını ortaya koymuşlardır. Altmış beş yaş üstündeki bireylerin adeta virüsü yaymakla hükmedildikleri, örneğin, bir haberde, otobüse alınmayınca aracın önüne yatan ileri yaşlı kadına 'Çekil pis koronalı!' diyerek hakaret edildiği konu edilmiştir (Heryasta.org, 2020).

Bu durumu eleştiren köşe yazıları (Aysever, 2020; Behramoğlu, 2020), Twitter paylaşımları (Kongar, 2021), podcastler (Çamlıdağ \& Köksalan, 2020) ve Youtube videoları (Medyascope, 2020) da konuya dikkat çekme konusunda etkili olmuştur. Kongar (2021) tepkisini“FIırıncılara da talimat yollayın da, 65 yaş üstü vatandaşlara ekmek de vermesinler!" tweeti ile paylaşmıştır. Yaşçı uygulamalara verdiği tepkilerle duruma ilişkin toplumsal farkındalığın artmasına büyük katkı sunan yazar Ataol Behramoğlu, 65 yaş ve üstündeki bireylere uygulanan kısıtlamaların, anayasanın ve temel insan haklarının eşitlik ilkesine aykırı olduğunu bildirerek durdurulmasını talep ederek dava açmıştır (Cumhuriyet, 2020a).

Nevşehir Belediyesi'nin kurduğu'Yaşlı İhbar Hattı' gazetelere haber olmuş, belediyenin resmi Twitter hesabından 'dışarıda 65 yaş üstü kişileri görenlerin ALO 153'ü aramaları' duyurusu yapılmıştır (Cumhuriyet, 2020b). Bir tür'avlama' gibi yansıtılan bu uygulamalar Türkiye'de yaşçılığın salgın döneminde vücut bulma şeklinin temsilleri niteliğindedir. Bir diğer habere göre (Diken, 2020) Bolu Belediye Başkanı Covid-19 nedeniyle hayatını kaybedenlerin çoğunun "bir ayağı çukurda olan insanlar" olduğu ifadesini kullanmıştır.

Bu paylaşımlar temelde iki yaygın tutumun yansımasıdır (Fraser et al., 2020). Illki, 65 yaş ve üstündeki bireylerin yüksek risk altında olmaları sebebiyle, adeta bu virüsten kaçışları olmadığı yönünde bir algının oluşması; savunmasız ve çaresiz bir durumda olmalarının, hastalanmalarının ve hatta yaşamlarını yitirmelerinin olağan bir durummuş gibi değerlendirilmesidir. İkincisi, genç nüfusun bu durumdan kendi yaş gruplarına ilişkin rahatlatııı ve kaygı düşürücü bir anlam çıkarmalarıdır. Sadece ileri yaştaki bireyleri risk altında görmeleri, kendilerini adeta 'yenilmez' ve 'güçlü' olarak algılayarak "bize birşey olmaz" yaklaşımıyla davranmaları sonucunu getirmektedir. Bu da, ayrımcı grubun tüm toplumu riske atmasına ve virüsün hızla yayılmasına yol açmaktadır. Unutulmamalıdır ki, bireylerin kendilerini ne kadar risk altında hissettikleri alınan önlemlere ve kısıtlamalara uyma düzeylerini belirleyecek yegâne etmendir (Harper, Satchell, Fido, \& Latzman, 2020). Bu nedenle halka iletilen mesajlar bu yönde büyük bir öneme sahiptir. 


\section{TARTIŞMA VE SONUÇ}

Görülen odur ki Covid-19 salgını aynı zamanda bir'ayrımcılık' salgınına dönüşmüştür. Belirli etnik kökenlerden gelen bireyler, yoksullar, azınlıklar ve göçmenler salgının ortaya çıkışına neden olmaktan, salgını yaymaktan sorumlu tutulmuş, yaşama tutunma ve sağlık hizmetlerinden yararlanma konusunda var olan yoksunluklarına yenileri eklenmiştir. Bu saydığımız'yaralanabilir' gruplar dışında, bu süreçte tüm dünyada ayrımcılığa maruz kalan bir diğer grup da kuşkusuz ileri yaştaki bireylerden oluşmaktadır.

İleri yaştaki bireylerin salgın açısından daha yüksek risk altında olduğu bilgisi sonucunda sokağa çıkma kısıtlamalarını ve önleyici tedbirleri bu doğrultuda belirlemek, onları korumak açısından akla yatkın görülebilir. Ancak, diğer yandan bu uygulama yaşçılığın tetikleyicisi de olabilmektedir (Ayalon et al., 2020; Lichtenstein, 2020; Vale, Stanley, Houston, Villalba, \&Turner, 2020).

Olumsuz ve düşmanca ayrımcılığın yanında şefkatli ayrımcılıkdan da kaçınmaya özen göstermek gerekmektedir. İleri yaştaki bireylerin özerkliklerine, yaşamları hakkında karar verme haklarına, aktif bir şekilde işlev görmelerine olanak tanımak, destek talep ettiklerinde uygun bir dil kullanarak destek olmak izlenmesi gereken yol olmalıdır. Pandemi öncesinde ve sırasında var olan, kuşkusuz sonrasında da varlığını sürdürecek olan yaşçılığın daha çok farkında olmak geleceğin yaşlıları olan gençlerin de adil, özerk ve eşitliğe dayalı bir yaşılıı evresi geçirmesi için son derece önemlidir.

Ayrımcılık hiçbir zaman salt tek bir sosyal sınıflandırmaya dayalı olmamıştır, çoğunlukla 'çoklu' bir yapıya sahiptir. Çoklu ayrımcılık (multiple discrimination), hem ayrımcı eylemlerin şiddeti hem de maruz kalan(lar) üzerindeki etkileri katlanarak artmış, oldukça yaygın bir ayrımcılık türüdür (Roseberry, 2011). Bu ayrımcılık türü Covid-19 döneminde yaşanan tüm eşitsizlikleri en iyi temsil eden kavramdır. Sadece yaşlı olmak değil, aynı zamanda emekli, kadın, homoseksüel, yoksul, engelli, belirli bir ülkenin vatandaşı olmak ve daha sayısız sosyal ve bireysel nitelik hissedilen ayrımcılığın katlanarak artmasına, yaşanan/yaşatılan mağduriyetin ve eşitsizliğin de bir o kadar güçlenmesine yol açmaktadır.

Ehni ve Wahl (2020, pp. 515-525), bu süreçte yaşçılıkla mücadele etmek için altının çizilmesi gereken gerçekleri ve çözüm önerilerini 6 temel önerme ile özetlemektedirler; 
1. İleri yaştaki bireylerden oluşan grup heterojendir, çoğunun sağlığı, yaşamsal işlevleri ve yetkinlikleri önyargıların önerdiğinden çok daha iyidir.

2. Bazı ülkelerin sağlık hizmetlerinden yararlanma konusunda yaş sınırı getirip belirli bir yaşın üzerindekileri adeta feda etmesi affedilemez bir insanlık suçudur.

3. Yaşçılık toplumların geleceği için son derece tehlikelidir ve kuşaklararası dayanışmayı artırmak son derece önemlidir.

4. İleri yaştaki bireylere paternalist, buyurgan, üstünlük içeren bir tutum sergilemek son derece yanlıştır.

5. Pandemi ileri yetişkinlik dönemindeki bireylerin iletişim teknolojilerini kullanma becerilerinin geliştirilmesi yönündeki desteği gerekli kılmıştır.

6. Salgınların neden olabileceği sonuçları öngörerek uygun politikalar geliştirebilmek için sadece virolojide değil gerontolojide de uzmanlaşmak gerektiği açıktır.

Sonuç olarak, açıkça görülmektedir ki pandemi yaşçılığı daha 'görünür' kılmıştır. Toplumların belleğini oluşturan, kültürel değerlerin sürdürülmesinde anahtar role sahip olan 65 yaş ve üstü bireylerin sağlıkları hem psikolojik hem de fizyolojik boyutta son derece önemlidir. Koruma amacıyla alınan önlemlerin, toplumu temel bazı ölçütlere göre sınıflara bölme yoluyla uygulamaya konulması beklenmedik olumsuz sonuçlar doğurabilir. Bireysel sağlığa bütüncül bir bakış açısıyla yaklaşmak, beden sağlığını düşünürken psikolojik iyilik halini göz ardı etmemek gerekmektedir. İnsanları kategorilere ayırmak çoğunlukla ötekileştirmeyi ve toplumsal ayrışmayı beraberinde getirmektedir. Bu ayrışma Sosyal Kimlik Kuramında da vurgulandığı gibi grup içi benzerliklerin ve gruplararası farklılıkların abartılarak algılanmasına ve iç grup kayırmacılığına yol açmaktadır. Bu gerçek dışı bir algılamadır ve bilinmektedir ki gruplar farklı niteliklere sahip, benzer yanları olsa da birçok açıdan farklı olan üyelerden oluşur. Yaş gruplarının 'biz' ve 'diğerleri' sınıflandırmasından hareketle geliştirecekleri ayrım kuşaklararası bağları zayıflatıp toplumsal birlik ve bütünlüğe gölge düşürebilmektedir. Her sosyal grup gibi, ileri yaştaki bireylerden oluşan grup da 'homojen' değildir. İleri yetişkinlik dönemindeki herkes'sağlıksız', 'güçsüz' ve'kırılgan' değildir. Çoğunun sağlıklı ve üretken bireyler olarak aktif yaşamlarını sürdürdüğü bilinmektedir. Sosyal Kimlik Kuramı ışığında baktığımızda, dünyaya bu ayrımla bakmak, iç-grup kayırmacılığı yoluyla yapılan sosyal 
karşılaştırma sonucunda bu yaş grubunda olmayan bireylerin kendilerini risk altında görmemelerine neden olmakta, kendilerini daha güvende hissetmelerini, hastalık ve ölüm korkusuyla başetmelerini kolaylaştırmaktadır. Yaş̧̧ılığın altında yatan bu ve benzeri mekanizmaları kavramak, bu tür savunucu yanlılıkların farkında olmak sorunla başa çıkma konusunda kuşkusuz önemli adımlardır.

Öte yandan, bu makalede de vurgulandığı gibi Psikanalitik Kuram, Evrimsel Yaklaşım, Yükleme Kuramı, Terör Yönetimi Kuramı, Sosyal Temsiller Kuramı ve Çerçeveleme Kuramı konuyu farklı boyutlarıyla ele alan, bu ayrımcılıkla mücadeleye ışık tutacak önermeleri olan kuramlardır. Tüm dünyada ve Türkiye'de yapılan çok sayıda araştırmanın bulgularının da gösterdiği gibi pandemi dönemlerinde ayrımcılık artan iletişim teknolojileriyle birlikte bambaşka bir boyuta taşınmıştır. Bu nedenle özellikle sosyal medyanın yeniden ürettiği ve daha hızlı yayıp pekiştirerek daha kalııı hale getirdiği yaşçı söylemlerin önüne geçmek için konu üzerine geliştirilecek iletişim politikalarına da büyük gereksinim duyulduğu açıktır.

Türkiye hızla yaşlanan bir toplum olma niteliği taşımaktadır. Yaşçı̆ı̆a ilişkin toplumsal farkındalığı eğitimden sağlığa ve politikaya kadar uzanan etkili uygulamalara yansıyacak düzeyde artırmanın gerekliliği açıktır. Başta psikoloji, sosyoloji, tıp, eğitim ve iletişim bilimleri gibi disiplinlerden uzmanların konu üzerine araştırmalar yürütmesi büyük bir önem arz etmektedir. Covid-19 pandemisi, etkin eğitimsel ve iletişimsel çabalarla, çocukluk döneminden başlayarak yaşçılığa yönelik evrensel bir mücadelenin gereğini gözler önüne sermiştir. Bu mücadelenin, Türkiye'de de hem yaşanan küresel salgın özelinde hem de tüm yaşama yayılmış olan yaşçılık ve diğer yaygın ayrımcılık türlerini kapsayacak şekilde yürütülmesinin önemi açıktır. Yaşçılık, daha önce de vurgulandığı gibi bu süreçte bir 'insan hakları ihlali'ne dönüşmüştür. Daha çok ileri yaş grubundaki bireyleri hedef alan, ancak öte yandan çocukları ve ergenleri de yer yer yaşçlık kurbanı konumuna getiren kısıtlamaların gerekliliği, yarar ve bedelleri sözü edilen bilim dallarının önermeleri ışığında irdelenmeli, bu tür adımlar özenle atılmalı, gelecekte yaşanması olası benzeri krizleri yönetme yolunda rehberlik edecek çıkarımlarda bulunulmalıdır. Öte yandan, her ne kadar evrensel olsa da kültüre özgü bir dokusu da olan yaşçıı̆̆ın ( Ng \& Lim, 2020) kuşaklararası bağları zedeleyen niteliğini bertaraf edecek şekilde, yaş grupları arasındaki dayanışmanın altını kültürel değerler ışığında çizerek vurgulayan, ileri yaştaki bireyleri 'bilge' olarak görme yönündeki geleneği canlandırmayı hedefleyen çalışmalar yürütmek de bir başka öneri olarak sunulabilir. 
Hakem Değerlendirmesi: Dış bağımsız.

Çıkar Çatışması: Yazar çıkar çatışması bildirmemiştir.

Finansal Destek: Yazar bu çalışma için finansal destek almadığını beyan etmiştir.

Peer-review: Externally peer-reviewed.

Conflict of Interest: The author has no conflict of interest to declare.

Grant Support: The author declared that this study has received no financial support.

\section{REFERENCES}

Allport, G. W. (1954). The nature of prejudice. Reading, MA: Addison-Wesley.

Assche, V., Politi, J., Van Dessel, E. P., \& Phalet, K. (2020). To punish or to assist? Divergent reactions to ingroup and outgroup members disobeying social distancing. The British Journal of Social Psychology, 59(3), 594-606. https://doi.org/10.1111/bjso.12395

Ayalon, L., Chasteen, A., Diehl, M., Levy, B. R., Neupert, S. D., Rothermund, K.,...Wahl, H. W. (2020). Aging in times of the Covid-19 pandemic: avoiding ageism and fostering intergenerational solidarity. The Journals of Gerontology, Series B, 76(2), 49-52. https://doi.org/10.1093/geronb/gbaa051

Aysever, E. (2020, 6 Nisan). Virüsle mücadele sınıfsaldır! Cumhuriyet. Retrieved from https://www.cumhuriyet. com.tr/yazarlar/enver-aysever/virusle-mucadele-sinifsaldir-1731466

Barrett, R., \& Brown, P. J. (2008). Stigma in the time of influenza: Social and institutional responses to pandemic emergencies. Journal of Infectious Diseases, 197(Suppl. 1), 34-37. https://doi.org/10.1086/524986

Becker, E. (1975). Escape from evil. New York: Free Press.

Behramoğlu, A. (2020, 19 Ağustos). Şu kahrolası 65 yaş ve üstü. Cumhuriyet. Retrieved from https://www. cumhuriyet.com.tr/yazarlar/ataol-behramoglu/su-kahrolasi-65-yas-ve-ustu-1759377

Brooke, J., \& Jackson, D. (2020). Older people and Covid-19: Isolation, risk and ageism. Journal of Clinical Nursing, 29(13-14), 2044-2046. https://doi.org/10.1111/jocn.15274

Budhwani, H., \& Sun, R. (2020). Creating Covid-19 stigma by referencing the novel coronavirus as the Chinese virus on Twitter: quantitative analysis of social media data. Journal of Medical Internet Research, 22(5). https:// doi.org/10.2196/19301

Bugental, D. B., \& Hehman, J. A. (2007). Ageism: A review of research and policy implications. Social Issues and Policy Review, 1(1), 173-216. https://doi.org/10.1111/j.1751-2409.2007.00007.x

Burger, J. M. (1992). Desire for control. New York, NY: Plenum.

Burke, J., Akinwotu, E., \& Kuo, L. (2020, Nisan 27). China fails to stop racism against Africans over Covid-19. The Guardian. Retrieved from https://www.theguardian.com/world/2020/apr/27/china-fails-to-stop-racismagainst-africans-over-Covid-19

Buss, D. M., \& Kenrick, D. T. (1998). Evolutionary social psychology. In D. T. Gilbert, S. T. Fiske, \& G. Lindzey (Eds.), The Handbook of Social Psychology (pp. 982-1026). Boston, MA: McGraw-Hill. 
Busza, J. R. (2001). Promoting the positive: Responses to stigma and discrimination in Southeast Asia. AIDS Care, 13(4), 441-456.

Butler, R. (1969). Age-Ism: another form of bigotry. Gerontologist, 9(4), 243-246.

Callaghan, K., \& Schnell, F. (2001). Understanding the consequences of group labeling for the women's movement. Women \& Politics, 23(4), 31-60. https://doi.org/10.1300/J014v23n04_02

Cogan, J. C., \& Herek, G. M. (1998). Stigma. In R. A. Smith (Ed.), The encyclopedia of AIDS: A social, political, cultural, and scientific record of the HIV epidemic (pp. 466-467). Chicago, IL: Fitzroy Dearborn.

Courtney, E. P., Goldenberg, J. L., \& Boyd, P. (2020). The contagion of mortality: A terror management health model for pandemics. The British Journal of Social Psychology, 59(3), 607-617. https://doi.org/10.1111/ bjso. 12392

Crandall, C. S., D’Anello, S., Sakalli, N., Lazarus, E., Nejtardt, G. W., \& Feather, N. T. (2001). An attribution value model of prejudice: Anti-fat attitudes in six nations. Personality and Social Psychology Bulletin, 27(1), 30-37. https://doi.org/10.1177/0146167201271003

Croucher, S. M., Nguyen, T., \& Rahmani, D. (2020). Prejudice toward Asian Americans in the COVID 19 pandemic: The effects of social media use in the United States. Frontiers in Communication, 5, Article 39. https://doi. org/10.3389/fcomm.2020.00039

Cumhuriyet (2020a, 13 Aralık). Ataol Behramoğlu, 65 yaş yasağına karşı dava açtı. Retrieved from https://www. cumhuriyet.com.tr/haber/ataol-behramoglu-65-yas-yasagina-karsi-dava-acti-1798220

Cumhuriyet (2020b, 21 Mart). Nevşehir Belediyesi, 'ALO 153 Yaşlı İhbar Hattı' oluşturdu. Retrieved from https:// www.cumhuriyet.com.tr/haber/nevsehir-belediyesi-yasli-ihbar-hatti-olusturdu-1728714

Çamlıdağ, S., \& Köksalan, M. (Producers). (2020, May 28). Oy ve ötesi podcast (1): Salgın ve yaşçılık [Video podcast]. Retrieved from https://oyveotesi.org/oy-ve-otesi-podcast-19-1-salgin-ve-yascilik/

Çayır, K. (2012). Yaşçılık/yaşa dayalı ayrımcılık. In K. Çayır ve M. A. Ceyhan (Eds.), Ayrımcılık: Çok boyutlu yaklaşımlar içinde (pp. 163-174). İstanbul, Turkey: Bilgi Üniversitesi Yayınları.

Çayır, K. (2018). Ders kitaplarında yaşılık temsili. In A. Duben (Ed.), Yaşlanma ve yaşlılık: Disiplinlerarası bakış açıları (pp. 79-97). İstanbul, Turkey: İstanbul Bilgi Üniversitesi Yayınları.

Demir, A. (2020). Covid-19 Pandemi sürecinde sosyoloji öğrencilerinin yaşçılığa karşı tutumları. Kuram ve Uygulamada Sosyal Bilimler Dergisi, 4(2), 12-25. https://doi.org/10.48066/kusob.825551

Demirtaş-Madran, H. A. (2020). Exploring the motivation behind discrimination and stigmatization related to covid-19: A social psychological discussion based on the main theoretical explanations. Frontiers in Psychology, 11, Article 569528. https://doi.org/10.3389/fpsyg.2020.569528

Devakumar, D., Bhopal, S. S., \& Shannon, G. (2020). Covid-19: the great unequaliser. Journal of the Royal Society of Medicine, 113(6), 234-235. https://doi.org/10.1177/0141076820925434

Diken (2020, 12 Eylül). Validen, 'Ölenlerin çoğunun bir ayağı çukurdaydı' diyen belediye başkanına tepki. Retrieved from https://www.diken.com.tr/olenlerin-cogunun-bir-ayagi-cukurdaydi-diyen-bolu-belediyebaskanina-validen-tepki-sozleri-uzucu/ 
Dollard, J., Miller, N. E., Doob, L. W., Mowrer, O. H., \& Sears, R. R. (1939). Frustration and aggression. London, United Kingdom: Yale University Press. https://doi.org/10.1037/10022-000

Duben, A. (Ed.). (2018). Yaşlanma ve yaşııık: Disiplinlerarası bakış açıları. İstanbul, Turkey: İstanbul Bilgi Üniversitesi Yayınları.

Dubey, S., Biswas, P., Ritwik, G., Chatterjee, S., Dubey, M. J., Chatterjee, S.,...Lavie, C. J. (2020). Psychosocial impact of Covid-19. Diabetes and Metabolic Syndrome: Clinical Research \& Reviews, 14(5), 779-788. https:// doi.org/10.1016/j.dsx.2020.05.035

Eagly, A. H., \& Chaiken, S. (1998). Attitude structure and function. In D. T. Gilbert, S. T. Fiske, \& G. Lindzey (Eds.), The handbook of social psychology (pp. 269-322). Boston, MA: McGraw-Hill.

Ehni, H.-J., \& Wahl, H.-W. (2020). Six propositions against ageism in the Covid-19 pandemic. Journal of Aging \& Social Policy, 32(4-5), 515-525. https://doi.org/10.1080/08959420.2020.1770032

Faulkner, J., Schaller, M., Park, J. H., \& Duncan, L. A. (2004). Evolved disease-avoidance mechanisms and contemporary xenophobic attitudes. Group Processes \& Intergroup Relations, 7(4), 333-353. https://doi. org/10.1177/1368430204046142

Festinger, L. (1954). A theory of social comparison processes. Human Relations, 7(2), 117-140. https://doi. org/10.1177/001872675400700202

Fiske, S. T. (2005). Social cognition and the normality of prejudgment. In J. F. Dovidio, P. Glick, and L. A. Rudman (Eds.), On the nature of prejudice: Fifty years after Allport (pp. 36-53). Oxford, United Kingdom: Blackwell.

Fiske, S. T., Cuddy, A. J., Glick, P., \& Xu, J. (2002). A model of (often mixed) stereotype content: Competence and warmth respectively follow from perceived status and competition. Journal of Personality and Social Psychology, 82(6), 878-902. https://psycnet.apa.org/doi/10.1037/0022-3514.82.6.878

Fraser, S., Lagacé, M, Bongué, B., Ndeye, N., Guyot, J., Bechard, L.,...,Tougas, F. (2020). Ageism and Covid-19: What does our society's response say about us? Age and Ageing, 49(5), 692-695. doi: 10.1093/ageing/afaa097.

Gilles, I., Bangerter, A., Clémence, A., Green, E. T., Krings, F., Mouton, A., Rigaud, D.,....Wagner-Egger, P. (2013). Collective symbolic coping with disease threat and othering: A case study of avian influenza. British Journal of Social Psychology, 52(1), 83-102. https://doi.org/10.1111/j.2044-8309.2011.02048.x

Giritli İnceoğlu, Y. (2021). Koronavirüs günlükleri. İstanbul, Turkey: Köprü Kitapları.

Giritli İnceoğlu, Y. (2020). Covid-19 pandemisi ve medya. In TTB Covid-19 pandemisi 6. ay değerlendirme raporu. 632643. Retrieved from https://www.ttb.org.tr/yayin_goster.php?Guid=42ee49a2-fb2d-11 ea-abf2-539a0e741e38 Giritli İnceoğlu, Y., \& Çoban S. (2021). Pandemi, neoliberalizm, medya. İstanbul, Turkey: Ayrıntı.

Goffman, E. (1974). Frame analysis: An essay on the organization of experience. Harvard University Press.

Goodwin, R., Haque, S., Neto, F., \& Myers, L. B. (2009). Initial psychological responses to Influenza A, H1N1 ('Swine flu'). BMC Infectious Diseases, 9, Article 166. https://doi.org/10.1186/1471-2334-9-166

Green, E. G. T., Krings, F., Staerklé, C., Bangerter, A., Clémence, A., Wagner-Egger, P., \& Bornand, T. (2010). Keeping the vermin out: Perceived disease threat and ideological orientations as predictors of exclusionary immigration attitudes. Journal of Community and Applied Social Psychology, 20(4), 299-316. https://doi.org/10.1002/casp.1037 
Greenberg, J., Landau, M. J., Kosloff, S., \& Solomon, S. (2009). How our dreams of death transcendence breed prejudice, stereotyping, and conflict: Terror management theory. In T. Nelson (Ed.), The handbook of prejudice, stereotyping, and discrimination (pp. 309-322). New York, NY: Psychology Press.

Greenberg, J., Pyszczynski, T., \& Solomon, S. (1986). The causes and consequences of a need for self esteem: A terror management theory. In R. F. Baumeister (Ed.), Public self and private self (pp. 189-212). New York, NY: Springer-Verlag.

Greenberg, J., Schimel, J., ve Martens, A. (2002). Ageism: Denying the face of the future. In T. D. Nelson (Ed.), Ageism: Stereotyping and prejudice against older persons (pp. 27-48). Cambridge, MA: MIT Press.

Guterres, A., (2020a, April 23). \#COVID19 is a public health emergency - that is fast becoming a human rights crisis. People -and their rights - must be front and centre. [Twitter]. Retrieved from https://twitter.com/ antonioguterres/status/1253177480418144256

Guterres, A., (2020b, May 13). Hate speech, stigma, and xenophobia continue to rise as a result of \#COVID19. [Twitter]. Retrieved from https://twitter.com/antonioguterres/status/1260396598737145857

Guttman, N., \& Lev, E. (2021). Ethical Issues in Covid-19 Communication to Mitigate the Pandemic: Dilemmas and Practical Implications. Health Communication, 36(1), 116-123, https://doi.org/10.1080/10410236.2020.1847439 Harper, C. A., Satchell, L., Fido, D., \& Latzman, R. (2020). Functional fear predicts public health compliance in the Covid-19 pandemic. PsyArXiv preprint. Retrieved from https://doi.org/10.31234/OSF.IO/JKFU3.

Harwood, J., Giles, H., \& Ryan, E. B. (1995). Aging, communication, and intergroup theory: Social identity and intergenerational communication. In J. F. Nussbaum \& J. Coupland (Eds.), LEA's communication series. Handbook of communication and aging research (pp. 133-159). Mahwah, NJ: Erlbaum.

He, J., He, L., Zhou, W., Nie, X., \& He, M. (2020). Discrimination and social exclusion in the outbreak of COVID 19. International Journal of Environmental Research and Public Health, 17(8), 29-33. https://doi.org/10.3390/ ijerph17082933

Hehman, J. A., \& Bugental, D. B. (2015). Response to patronizing communication and factors that attenuate those responses. Psychology \& Aging, 30, 552-560.

Heryasta.org (2020). Yaş ayrımcılığıyla mücadele birinci görevimiz. Retrieved from https://www.heryasta. org/2020/08/05/yas ayrimciligiyla-mucadele-birincil-gorevimiz/

Human Rights Watch. (2020, Mach 19). Human rights dimensions of Covid-19 response. Retrieved from https:// www.hrw.org/news/2020/03/19/human-rights-dimensions-Covid-19-response\#_Toc35446585.

Iversen, T. N., Larsen, L., \& Solem, P. E. (2009). A conceptual analysis of ageism. Nordic Psychology, 61(3), 4-22. https://doi.org/10.1027/1901-2276.61.3.4

Jetten, J., Haslam, S. A., Cruwys, T., \& Branscombe, N. R. (2018). Social identity, stigma, and health. In B. Major, J. F. Dovidio, \& B. G. Link (Eds.), The oxford handbook of stigma, discrimination, and health (pp. 301-316). Oxford, United Kingdom: Oxford University Press.

Jetten, J., Reicher, S. D., Haslam, S. A., \& Cruwys, T. (Eds.) (2020). Together apart: The psychology of Covid-19. London, United Kingdom: Sage. 
Jimenez-Sotomayor, M. R., Gomez-Moreno, C., \& Soto-Perez-De-Celis, E. (2020). Coronavirus, ageism, and Twitter: an evaluation of tweets about older adults and Covid-19. Journal of the American Geriatrics Society, 68(8), 1661-1665. https://doi.org/10.1111/jgs.16508

Joffe, H. (1999). Risk and 'the other'. Cambridge, United Kingdom: Cambridge University. https://doi.org/10.1017/ CBO9780511489846

Joffe, H., \& Staerklé, C. (2007). The centrality of the self-control Ethos in western aspersions regarding outgroups: A social representational approach to stereotype content. Culture \& Psychology, 13(4), 395-418. https://doi. org/10.1177/1354067X07082750

Joffe, H., Washer, P., \& Solberg, C. (2011). Public engagement with emerging infectious disease: the case of MRSA in Britain. Psychology \& Health, 26(6), 667-683. https://doi.org/10.1080/08870441003763238

Jost, J. T., \& Van der Toorn, J. (2011). System justification theory. In K. Dowding (Ed.), Encyclopedia of power (pp. 649-653). Thousand Oaks, CA: Sage.

Kim, C. H. (2020, April 1). Anti-Asian racism has come roaring back with Covid-19: Cathy Park Hong on being Asian American. The Guardian. Retrieved from https://www.theguardian.com/books/2020/apr/01/cathypark-hong-minor-feelings

Kite, M. E., Stockdale, G. D., Whitley, B. E., Jr., \& Johnson, B. T. (2005). Attitudes toward younger and older adults: An updated meta-analytic review. Journal of Social Issues, 61(2), 241-266. https://doi.org/10.1111/ j.1540-4560.2005.00404.x

Kydd, A., \& Fleming, A. (2015). Ageism and age discrimination in health care: Fact or fiction? A narrative review of the literature. Maturitas, 81(4), 432-438. https://doi.org/10.1016/j.maturitas.2015.05.002

Kongar, E., (2021, April 15). Fırıncılara da talimat yollayın da, 65 yaş üstü vatandaşlara ekmek de vermesinler! [Twitter]. 15 Nisan. Retrieved from https://twitter.com/emrkongar/status/1382606617775108096

Lakoff, G. (2004). Don't think of an elephant. White River Junction, VT: Chelsea Green.

Lerner, M. J. (1980). The belief in a just world. In M. J. Lerner (Ed.), The belief in a just world. Perspectives in social psychology (pp. 9-30). Boston, MA: Springer.

Levy, S. R., \& Hughes, J. M. (2009). Development of racial and ethnic prejudice among children. In T. Nelson (Ed.), Handbook of prejudice, stereotyping, and discrimination (pp. 23-42). New York, NY: Psychology Press.

Lichtenstein, B. (2020). From "coffin Dodger" to "boomer Remover": Outbreaks of ageism in three countries with divergent approaches to coronavirus control. The Journals of Gerontology, Series B, Article gbaa102 (Gelişmiş çevrim içi yayın). https://doi.org/10.1093/geronb/gbaa102

Lippmann, W. (1922). Public opinion. Harcourt, Brace.

Liu, Y., Finch, B. K., Brenneke, S. G., Thomas, K., \& Le, P.-T. D. (2020). Perceived discrimination and mental distress amid the Covid-19 pandemic: Evidence from the understanding America study. American Journal of Preventive Medicine, 59(4), 481-492. http://dx.doi.org/10.1016/j.amepre.2020.06.007

Mak, W. W., Mo, P. K., Cheung, R. Y., Woo, J., Cheung, F. M., \& Lee, D. (2006). Comparative stigma of HIV/AIDS, SARS, and tuberculosis in Hong Kong. Social Science \& Medicine, 63(7), 1912-1922. 
Mayor, E., Eicher, V., Bangerter, A., Gilles, I., Clémence, A., \& Green, E. G. T. (2013). Dynamic social representations of the 2009 H1N1 pandemic: Shifting patterns of sense-making and blame. Public Understanding of Science, 22(8), 1011-1024. https://doi.org/10.1177/0963662512443326

Medyascope (2020, 7 Haziran). Sosyopolitik. Prof. Dr. Kenan Çayır ile salgının ortaya çıkardığı ayrımcılık; Yaşçılık. [Video]. Retrieved from https://www.youtube.com/watch?v=ioJ6hr8GTMM

Nature (2020). End coronavirus stigma now. Nature 580, 165. Retrieved from https://media.nature.com/original/ magazine-assets/d41586-020-01009-0/d41586-020-01009-0.pdf

Nelson, T. D. (2016). Ageism. In T. Nelson (Ed.), Handbook of prejudice, stereotyping, and discrimination (pp. 337353). New York, NY: Psychology Press.

Ng, R., \& Lim, J. (2020). Ageism linked to culture, not demographics: Evidence from an 8-billion-word corpus across 20 countries. The Journals of Gerontology: Series B, Article gbaa181. https://doi.org/10.1093/geronb/gbaa181

OHCHR. (2020). No exceptions with Covid-19: Everyone has the right to life-saving interventions - UN experts say. Geneva, Switzerland: Office of the United Nations High Commissioner for Human Rights. Retrieved from https://www.ohchr.org/EN/NewsEvents/Pages/DisplayNews.aspx?NewsID=25746\&LangID=E .

Oldstone, M. B. A. (1998). Viruses, plagues, and history. New York, NY: Oxford University Press.

Palmore, E. B. (1999). Ageism: Negative and positive. New York, NY: Springer.

Panagiotis, P., Willis, P., Ray, M., Deusdad, B., Lonbay, S., \& Donnelly, S. (2020). Older people in the context of Covid-19: A European perspective. Journal of Gerontological Social Work. https://doi.org/10.1080/01634372. 2020.1821143

Perrigo, B. (2020, April 3). It was already dangerous to be Muslim in India. Then came the coronavirus. Time. Retrieved from https://time.com/5815264/coronavirus-india-islamophobia-coronajihad/.

Previtali, F., Keskinen, K., Niska, M., \& Nikander, P. (2020). Ageism in working life: A scoping review on discursive approaches. The Gerontologist, Article gnaa119. https://doi.org/10.1093/geront/gnaa119

Rahman, A., Jahan, Y. (2020). Defining a'risk group' and ageism in the era of Covid-19. Journal of Loss and Trauma, 25(8), 631-634. https://doi.org/10.1080/15325024.2020.1757993

Roseberry, L. (2011). Multiple discrimination. In M. Sargeant (Ed.), Age discrimination and diversity: Multiple discrimination from an age perspective (pp. 16-40). Cambridge, UK: Cambridge University Press. https://doi. org/10.1017/CBO9780511777196

Ryan, E. B., Giles, H., Bartolucci, G., \& Henwood, K. (1986). Psycholinguistic and social psychological components of communication by and with the elderly. Language \& Communication, 6(1-2), 1-24. https://doi. org/10.1016/0271-5309(86)90002-9

Sargeant, M. (2011). Age discrimination and diversity, multiple discrimination from an age perspectives. Cambridge, UK: Cambridge University Press.

Savulescu, J., \& Cameron, J. (2020). Why lockdown of the elderly is not ageist and why levelling down equality is wrong. Journal of Medical Ethics, 46(11), 717-721. 
Schmitt, M. T., Branscombe, N. R., Postmes, T., \& Garcia, A. (2014). The consequences of perceived discrimination for psychological well-being: a meta-analytic review. Psychological Bulletin, 140(4), 921-948.

Schnell, F., McConatha, J. T., Magnarelli, J., \& Fry, D. (2020). Ageism and perceptions of vulnerability: Framing of age during the during the Covid-19 Pandemic. Retrieved from https://www.wcupa.edu/sciences-mathematics/ politicalScience/documents/FramingAgeDuringCovid.pdf.

Stechemesser, A., Wenz, L., \& Levermann, A. (2020). Corona crisis fuels racially profiled hate in social media networks. E Clinical Medicine, 23, Article 100372. https://doi.org/10.1016/j.eclinm.2020.100372

Stroebe, W., \& Insko, C. A. (1989). Stereotype, prejudice, and discrimination: Changing conceptions. In D. Bar-Tal, C. F. Graumann, A. W. Kruglanski, \& W. Stroebe (Eds.), Theory and research in stereotyping and prejudice (pp. 3-34). New York, NY: Springer.

Tabri, N., Hollingshead, S., \& Wohl, M. J. A. (2020, March 31). Framing Covid-19 as an existential threat predicts anxious arousal and prejudice towards Chinese people. PsyArXiv Preprints. https://doi.org/10.31234/osf.io/mpbtr.

Tajfel, H. (Ed.). (1978). Differentiation between social groups: Studies in the social psychology of intergroup relations. Cambridge, MA: Academic Press.

Terkildsen, N., Schnell, F. I., \& Ling, C. (1998). Interest groups, the media, and policy debate formation: An analysis of message structure, rhetoric, and source cues. Political Communication, 15(1), 45-61.

Tuna Uysal, M., \& Tan Eren, G. (2020). Covid-19 sürecinde sosyal medyada yaşlılara yönelik ayrımcılık: Twitter örneği. Turkish Studies, 15(4), 1147-1162. http://dx.doi.org/10.7827/TurkishStudies.44396

Turner, J. C., Hogg, M. A., Oakes, P. J., Reicher, S. D., \& Wetherell, M. S. (1987). Rediscovering the social group: A selfcategorization theory. Blackwell.

Vale, M. T., Stanley, J. T., Houston, M. L., Villalba, A. A., \& Turner, J. R. (2020). Ageism and behavior change during a health pandemic: A preregistered study. Frontiers in Psychology, 11, Article 587911. doi: 10.3389/ fpsyg.2020.587911.

Vervaecke, D., \& Meisner, B. A. (2020). Caremongering and assumptions of need: The spread of compassionate ageism during Covid-19, The Gerontologist, Article gnaa131, https://doi.org/10.1093/geront/gnaa131

Whitley, B. E., \& Kite, M. E. (2009). The psychology of prejudice and discrimination. Belmont, CA: Wadsworth.

Williams, J., Gonzalez-Medina, D., \& Le, Q. (2011). Infectious diseases and social stigma. Applied Innovations and Technologies, 4(1), 58-70.

WHO - World Health Organization (2020a). Ageing and health. Retrieved from https://www.who.int/news-room/ factsheets/detail/ageing-and-health

WHO - World Health Organization (2020b). Risks and safety for older people. Retrieved from https://www.who. int/newsroom/q-a-detail/coronavirus-disease-Covid-19-risks-and-safety-for-older-people

WHO - World Health Organization (2020c). Rolling updates on coronavirus disease (Covid-19). Retrieved from https://www.who.int/emergencies/diseases/novel-coronavirus-2019 
WHO - World Health Organization (2020d). WHO Director -General's opening remarks at the media briefing on Covid-19-11 March 2020. Retrieved from https://www.who.int/dg/speeches/detail/who-director-general-sopening-remarks-at-the-media-briefing-on-Covid-19---11-march-2020

WHO - World Health Organization (2020e). WHO timeline-Covid-19. Retrieved from https://www.who.int/ newsroom/detail/27-04-2020-who-timeline---Covid-19

Yaşar, Ö., \& Avcı, N. (2020). Değişen yaşlılık algısı: Covid-19 ile damgalanan yaşlılar. Turkish Studies, 15(4), 12511273. https://dx.doi.org/10.7827/TurkishStudies.44275 